January 2022

\title{
Book Review: Knowledge Justice: Disrupting Library and Information Studies Through Critical Race Theory, Sofia Y. Leung and Jorge R. López-McKnight
}

Jessica Nombrano Larsen

San Jose State University, jessica.n.larsen@sjsu.edu

Follow this and additional works at: https://scholarworks.sjsu.edu/ischoolsrj

Part of the Archival Science Commons, Cataloging and Metadata Commons, Collection Development and Management Commons, Information Literacy Commons, Museum Studies Commons, Scholarly Communication Commons, and the Scholarly Publishing Commons

\section{Acknowledgements}

Thank you to my family for all their love and support. Many thanks to Professor José A.

Aguiñaga for supporting this work.

\section{Recommended Citation}

Nombrano Larsen, J. (2022). Book Review: Knowledge Justice: Disrupting Library and Information Studies Through Critical Race Theory, Sofia Y. Leung and Jorge R. López-McKnight. School of Information Student Research Journal, 11(2). https://doi.org/10.31979/2575-2499.110204 Retrieved from https://scholarworks.sjsu.edu/ischoolsrj/vol11/iss2/4

This article is brought to you by the open access Journals at SJSU ScholarWorks. It has been accepted for inclusion in School of Information Student Research Journal by an authorized administrator of SJSU ScholarWorks. For more information, please contact scholarworks@sjsu.edu. 


\section{Book Review: Knowledge Justice: Disrupting Library and Information Studies Through Critical Race Theory, Sofia Y. Leung and Jorge R. López-McKnight}

\section{Keywords}

critical race theory, diversity, BIPOC, library and information professionals

\section{Acknowledgements}

Thank you to my family for all their love and support. Many thanks to Professor José A. Aguiñaga for supporting this work.

\section{About Author}

Jessica Nombrano Larsen is pursuing her MLIS degree at San Jose State University. She is Program Manager of the Empowering Autistic Scholars Program at California Polytechnic State University, San Luis Obispo. She earned her M.A. in English from California Polytechnic State University, San Luis Obispo in 2020. 
Leung, S. Y., \& Lopez-McKnight, J. R. (Eds). (2021). Knowledge justice: Disrupting library and information studies through critical race theory. MIT Press.

Despite decades of library diversity initiatives, librarians are still $83 \%$ white. Black, Indigenous, and People of Color (BIPOC) are severely underrepresented in librarianship as a result of the very structures and policies underlying Library and Information Science (LIS). These structures maintain the white cultural dominance that continues to shape our collections, archives, programs, and services, as well as the policies governing the recruitment, retention, and promotion of librarians of color. BIPOC professionals are too often left out of discussions about making LIS more equitable and are instead tasked with carrying out diversity initiatives that fail to create meaningful change. Determined to transform the LIS landscape into one of justice and equity for all, editors Sofia Leung and Jorge Lopez-McKnight partnered with thirty other BIPOC professionals to create the masterful Knowledge Justice: Disrupting Library and Information Studies Through Critical Race Theory. Using a Critical Race Theory (CRT) framework, they detail their experiences as BIPOC professionals in a predominately white field. This innovative work presents an uncompromisingly honest view of the state of our discipline as the authors seek to open our eyes to the complex workings of White Supremacy in LIS. They want to move CRT to the forefront of discussions regarding oppression in LIS, create a healing community that empowers its members to undertake transformative change, and provide strategies and recommendations we can use to revolutionize our discipline and make it "antiracist, anti-oppressive, and equitable" (Leung \& Lopez-McKnight, 2021, p. 12).

Per Leung and Lopez-McKnight, our society's refusal to admit that White Supremacy is ingrained in our laws and institutions, including our libraries and archives, is the primary reason that racial justice is still so elusive decades after the end of the mainstream Civil Rights movement. Our adoption of a liberal diversity framework that espouses color blindness allows the dominant social group (i.e., white, middle class, Christian, able-bodied, heterosexual men) to maintain the status quo, all the while pretending a sincere interest in solving the diversity problem. Of course, this "performative commitment to diversity" (Leung \& LopezMcKnight, 2021, p. 4) will not eradicate racism, and harms those it purports to help. Diversity residencies created for underrepresented academic librarians are an example of this. Individuals are placed in short-term positions, typically must perform diversity and inclusion work on top of what their full-time position requires and are often the only librarian of color in their institution, requiring them to assimilate to white cultural standards to be successful or risk being driven out. This system may nominally increase the number of racialized bodies in academic libraries, but no one benefits from a diversity that is only skin deep.

Part of the power of this text is that the writers have a real, vested interest in what they are writing about. Editors Leung, a librarian, consultant, educator, and facilitator who works with educational institutions to develop workshops and trainings that employ anti-racist and anti-oppressive frameworks, and LopezMcKnight, a faculty librarian at Austin Community College, forged a bond as a 
result of their dedication to exploring CRT's applications in LIS. Written by and for BIPOC, this text is meant to inspire and empower its readers, including those with little knowledge of CRT. Their ardent introduction includes a brief history of CRT, as well as an explanation of its methodologies and tenets, which effectively orient the reader and provide the requisite background information to enable the reader to fully engage with the work. The book is composed of three parts, each containing multiple chapters focused on interconnected themes, with every section beginning with an introduction penned by a different CRT scholar. Each chapter is centered around multiple tenets of CRT and reveals the systemic racism the authors have experienced during their careers.

In Part I, "Destroy White Supremacy," the writers utilize counterstorytelling, racism as ordinary, whiteness as property, and critique of liberalism to break down the institutional fallacy of neutrality. Neutrality promotes the idea that library staff must be fair and unbiased because libraries were developed on democratic principles and librarians are expected to espouse the core values defined by the ALA-including access, democracy, diversity, the public good, service to all library users, and social responsibility. Morales and Williams extend the concept of inherent bias to information itself. Consciously or not, human biases affect everything we do, including the research we conduct, the works we publish, the collections we develop, and the information we provide our patrons. Epistemic supremacy, which destroys the knowledge systems of marginalized groups to uphold those of the dominant class, contributes to the proliferation of biased knowledge and institutional racism. Librarians, archivists, and cataloguers wield incredible power in this respect; they can dismantle epistemic supremacy by giving equal space to the works of authors of all races and ethnicities, providing accurate stories and representations of POC, and ensuring the discoverability of the works of authors of color.

In Part II, "Illuminate Erasure," authors use CRT to develop strategies of resistance and transformation, including utilizing voice and counterstorytelling to expose exclusionary practices in scholarly communication, collection development, and information access that disenfranchise BIPOC library staff and patrons. Natarajan uses counterstorytelling to challenge the master narratives that perpetuate the stigma that POC are somehow deficient and must be assimilated to save them from themselves. This includes preventing them from accessing culturally relevant information about their communities and histories. Walker frames counternarrative and collection development as important tools to combat the misrepresentation of Black people resulting from the many one-sided stories found in libraries.

In Part III, "Radical Collective Imaginations toward Liberation," the writers use storytelling to "illuminate and explore experiences of racialized oppression while also envisioning more liberatory and emancipatory futures" (Leung \& McKnight, 2021, p. 220). Espinal, Hathcock and Rios use counterstorytelling to reveal the weaknesses inherent in the diversity narrative embraced by LIS and replace it with a transformative racial equity project to dewhiten LIS. The project included reallocating part of the library's budget to help BIPOC staff obtain their Master of Library and Information Science (MLIS) degree. Quiñonez, Nataraj, and 
Olivas challenge the fallacy that Higher Education is either neutral or objective, and utilize validation theory, community cultural wealth, and relational-cultural theory to "empower both students and librarians to assert their rightful places as scholars and members of a larger academic community" (Leung \& McKnight, 2021, p. 241).

While the authors make an excellent argument for the use of CRT in LIS and give space to many BIPOC voices across the field, representatives of two important groups are missing: library support staff and faculty teaching CRT in LIS programs. Library staff are vital to keeping libraries and archives running, but their work is often overlooked because of their lack of status. This book would have been even stronger had their voices been included because they add the element of class to the discussion and face even more challenges than higher-level personnel. It would also have been informative to hear from instructional faculty, who could have detailed their challenges with teaching CRT in a hostile environment and what strategies and recommendations they have for bringing it to the fore in LIS.

This is not your typical scholarly text. It is not written in formal academic English but in dynamic, evocative language that is representative of the vibrance and individuality of the writers and reiterates that all voices have value; there is more than one valid way to engage in scholarly communication. If utilized widely, this book has the potential to revolutionize LIS education. It provides enlightenment, hope, and a sense of community; it also reminds us that there are no quick or easy solutions. Many of the strategies provided require money, time, and power that many of us do not have. However, one important thing we can do is advocate for the addition of this text to foundational LIS courses. While it was written to create community and inspire solidarity among geographically isolated BIPOC students and professionals, it has the potential to reach a much wider audience. Studying this book in foundational LIS courses would bring a vital discussion to the attention of students of all backgrounds and career aspirations. It is an important text to read as a community; there is a lot to unpack, the writing is very different from most academic works, and students who have not encountered CRT before may have difficulty keeping an open mind. Allowing students to come together to discuss the text will enable them to engage with it more thoroughly and better understand the wide-spread damage resulting from the current system. These enlightened students will be much more likely to center CRT in the discussion of equity and prioritize social justice in their work. Leung, Lopez-McKnight, and their contributors have written a powerful call to action: it is now up to us to take up their challenge.

\section{References}

Leung, S. Y., \& Lopez-McKnight, J. R. (Eds). (2021). Knowledge justice: Disrupting library and information studies through critical race theory. MIT Press. 